УДК 621.311

DOI: 10.20535/2079-5688.0.33.96601

V.S. Stepashko, doctor of technical sciences, professor, A.R. Trachuk, postgraduate (National Technical University of Ukraine "Igor Sikorsky Kyiv Polytechnic Institute")

\title{
APPLIED IMPLEMENTATION OF GROUP METHOD OF DATA HANDLING FOR MODELING THE PETROLEUM CONSUMPTION IN UKRAINE
}

B.C. Степашко, докт. техн. наук, професор, А.Р. Трачук, аспірант (КПІ ім. Ігоря Сікорського)

\section{ПРИКЛАДНА РЕАЛІЗАЦІЯ МЕТОДУ ГРУПОВОГО УРАХУВАННЯ АРГУМЕНТІВ ДЛЯ МОДЕЛЮВАННЯ СПОЖИВАННЯ НАФТИ В УКРАЇНI}

Considered issues of petroleum consumption in Ukraine. The dynamics of petroleum consumption and the proposed guidelines gait efficient use of petroleum. Researched and projected scenarios projected of petroleum consumption in general throughout Ukraine.

Keywords: energy balance; energy conservation; energy efficiency; energy statistics.

Розглянуті проблемні питання споживання нафти по Україні. Проаналізовано динаміку споживання нафти та запропоновані методичні рекомендачії ходо ефективного використання нафти. Досліджені та зпрогнозовані прогнозні сценарії споживання нафти загалом по всій Украӥні.

Ключові слова: енергетичний баланс; енергозбереження; енергоефективність; енергетична статистика.

Рассмотрены проблемные вопросы потребления нефти по Украине. Проанализирована динамика потребления нефти и предложень методические рекомендации путем эффективного использования нефти и нефтересурсов. Исследованы и спрогнозированные прогнозные сценарии потребления нефти в целом по всей Украине.

Ключевые слова: энергетический баланс; энергосбережение; энергоэффективность; энергетическая статистика.

Introduction. The basic foundation of the formation of the Ukraine grid construction is forecasting scenarios for different types of energy and the various criteria for effective use of energy resources. The problem of efficient use of energy resources raises crucial for sustainable economic development against the backdrop of energy saving national economy depends on energy imports, on the one hand, and rising prices for these resources. The solution to this problem is not only with 
ensuring energy security, but also with the level of development of regions and the quality of life of its population. [1]

Forecasting of petroleum consumption in Ukraine today is an extremely important issue of strategic importance since conducted through analysis and building predictive models will be possible to develop guidelines for the efficient production and consumption across Ukraine as a whole.

Aim of the work is to develop methodical recomendations on predicting of petroleum consumption in Ukraine through the use of the group method of data handling..

Statement of material and research results. The level of energy has a decisive impact on the economy of the state, resolving social problems and living standards of citizens. Changes in energy prices immediately reflected in all industries, and the rest, the price of the final product. Therefore, instead of quantitative objectives of energy development, which was followed by Ukraine's economy in recent decades, energy has to go to power sustainable economic development, focused on that now developed countries. The said research leads scientists to balance the energy balance of Ukraine, which determined the relevance of the work. In the traditional understanding of energy balance is the ratio between the extraction (production) and consumption of different types of energy resources. [2]

At the heart of the development of fuel and energy balance is a set of strategic statements of economic development, the definition of forecast volumes of energy consumption, based on adopted policies to increase energy efficiency, the development of fuel and energy complex and evaluating opportunities extraction and production of fuel and energy, as well as the formation of areas of import- exporting policy and determine the volume of purchase and sale of energy. [3]

One of the mathematical methods of forecasting is group method of data handling, which allows you to build adequate predictive models of energy consumption in the system of Ukraine's energy balance. [4]

By the use of a group method of data handling and by using modern software were built predictive models of petroleum consumption in the system of Ukraine's energy balance:

1. Predictive system model, 2 lags:

$$
\begin{aligned}
& \mathrm{Y}(1)=2.2580+0,7135 * \mathrm{Y} 1(-1)-0,0.3915 * \mathrm{Y} 1(-2)+0,1544 * \mathrm{Y} 3(-1) \\
& \mathrm{Y}(2)=11.0662+0,6253 * \mathrm{Y} 2(-1)+0,8652 * \mathrm{Y} 2(-2)-1.0759 * \mathrm{Y} 3(-2) \\
& \mathrm{Y}(3)=6.2975-0.8208 * \mathrm{Y} 3(-1)-0.0460 * \mathrm{Y} 3(-2)
\end{aligned}
$$


Initial data of petroleum consumption

\begin{tabular}{|l|c|c|c|}
\hline \multirow{2}{*}{ Year } & $\begin{array}{l}\text { Petroleum production, } \\
\text { total, mln t }\end{array}$ & $\begin{array}{l}\text { Petroleum } \\
\text { consumption, along } \\
\text { with the processing of } \\
\text { export, total, mln t }\end{array}$ & $\begin{array}{l}\text { Petroleum imports, } \\
\text { total, mln t }\end{array}$ \\
\cline { 2 - 4 } & Y1 & Y2 & Y3 \\
\hline 2006 & 5,4 & 19,5 & 15,5 \\
\hline 2007 & 6,1 & 23,4 & 16,8 \\
\hline 2008 & 6,8 & 25,7 & 18,3 \\
\hline 2009 & 7,9 & 29,5 & 21,9 \\
\hline 2010 & 8,7 & 32,0 & 23,3 \\
\hline 2011 & 8,8 & 33,6 & 24,6 \\
\hline 2012 & 9,0 & 34,2 & 25,1 \\
\hline 2013 & 9,1 & 34,9 & 25,7 \\
\hline 2014 & 9,1 & 35,3 & 26,3 \\
\hline 2015 & 9,3 & 36,0 & 26,7 \\
\hline
\end{tabular}

Results of approximation and forecast for the next 5 years

The first indicator Y1 - Petroleum production, total, $\mathrm{mln} t$ is given in Table 2

Petroleum production, total, $\mathrm{mln} \mathrm{t}$

\begin{tabular}{|c|c|c|c|c|c|c|c|c|c|}
\hline Year & 2006 & 2007 & 2008 & 2009 & 2010 & 2011 & 2012 & 2013 & 2014 \\
\hline $\begin{array}{c}\text { Initial } \\
\text { data }\end{array}$ & 5,4 & 6,1 & 6,80 & 7,90 & 8,70 & 8,80 & 9,00 & 9,10 & 9,10 \\
\hline Forecast & & & 7,09 & 7,92 & 8,44 & 8,73 & 8,92 & 9,08 & 9,22 \\
\hline
\end{tabular}

Continuation of Table 2

\begin{tabular}{|c|c|c|c|c|c|c|}
\hline Year & 2015 & 2016 & 2017 & 2018 & 2019 & 2020 \\
\hline Initial data & 9,30 & & & & & \\
\hline Forecast & 9,35 & 9,45 & 13,17 & 12,35 & 10,30 & 9,14 \\
\hline
\end{tabular}

The second indicator Y2 - Petroleum consumption, along with the processing of export, total, $\mathrm{mln} \mathrm{t}$ is given in Table 3

Table 3

Petroleum consumption, along with the processing of export, total, mln t

\begin{tabular}{|c|c|c|c|c|c|c|c|c|c|}
\hline Year & 2006 & 2007 & 2008 & 2009 & 2010 & 2011 & 2012 & 2013 & 2014 \\
\hline Initial data & 19,5 & 23,4 & 25,70 & 29,50 & 32,00 & 33,60 & 34,20 & 34,90 & 35,30 \\
\hline Forecast & & & 25,89 & 29,43 & 31,02 & 32,87 & 33,72 & 34,57 & 34,86 \\
\hline
\end{tabular}




\begin{tabular}{|c|c|c|c|c|c|c|}
\hline Year & 2015 & 2016 & 2017 & 2018 & 2019 & 2020 \\
\hline Initial data & 36,00 & & & & & \\
\hline Forecast & 35,03 & 35,82 & 33,47 & 33,93 & 30,61 & 28,99 \\
\hline
\end{tabular}

The third indicator Y3 - Petroleum imports, total, mln $\mathrm{t}$ is given in Table 4

Table 4

Petroleum imports, total, $\mathrm{mln} \mathrm{t}$

\begin{tabular}{|c|c|c|c|c|c|c|c|c|c|}
\hline Year & 2006 & 2007 & 2008 & 2009 & 2010 & 2011 & 2012 & 2013 & 2014 \\
\hline Initial data & 15,5 & 16,8 & 18,30 & 21,90 & 23,30 & 24,60 & 25,10 & 25,70 & 26,30 \\
\hline Forecast & & & 19,34 & 21,53 & 23,17 & 24,42 & 25,32 & 25,93 & 26,29 \\
\hline
\end{tabular}

\begin{tabular}{|c|c|c|c|c|c|c|}
\hline Year & 2015 & 2016 & 2017 & 2018 & 2019 & 2020 \\
\hline Initial data & 26,70 & & & & & \\
\hline Forecast & 26,68 & 26,68 & 24,05 & 24,0 & 23,14 & 22,51 \\
\hline
\end{tabular}

Interconnection imports of oil and gas

$$
\begin{aligned}
& \mathrm{Y} 1=0.9017 * \mathrm{Y} 1(-1)+0.0775 * \mathrm{Y} 2(-2) \\
& \mathrm{Y} 2=0.0369 * \mathrm{Y} 1(-1)+0.6177 * \mathrm{Y} 2(-1)+0.2820 * \mathrm{Y} 2(-2)
\end{aligned}
$$

The fourth indicator Y4 - Petroleum imports, total, $\mathrm{mln} t$ is given in Table 5

Table 5

Petroleum imports, total, mln t

\begin{tabular}{|c|c|c|c|c|c|c|c|c|c|c|}
\hline Year & 2006 & 2007 & 2008 & 2009 & 2010 & 2011 & 2012 & 2013 & 2014 & 2015 \\
\hline $\begin{array}{c}\text { Initial } \\
\text { data }\end{array}$ & 54,1 & 52,8 & 47,5 & 45.4 & 42,1 & 40,3 & 39.6 & 37,3 & 33.6 & 31,3 \\
\hline Forecast & & & 48,49 & 45,56 & 42,61 & 40,02 & 37,64 & 35,47 & 33,48 & 31,66 \\
\hline
\end{tabular}

Continuation of Table 5

\begin{tabular}{|c|c|c|c|c|c|}
\hline Year & 2016 & 2017 & 2018 & 2019 & 2020 \\
\hline Initial data & & & & & \\
\hline Forecast & 29,79 & 19,39 & 21,27 & 19,49 & 18,89 \\
\hline
\end{tabular}

Discussion. The basic method of building predictive models of petroleum consumption has been selected the group method of data handling, because through this unique method was possible to build a multidimensional multifactor forecasting model of petroleum consumption in the system of energy balance in Ukraine, which will take into account all the important energy performance in the petroleum industry in the complex. Using group method of data handling to build petroleum consumption forecasting scenarios enabled to view advanced options for the future 
development of the sector of the petroleum industry in Ukraine for the next 5 years and made it possible to see clearly at that scenario can develop petroleum industry in Ukraine and were predicted important key indicators. [5]

\section{Conclusion}

Through analysis of the dynamics of petroleum consumption in Ukraine and analysis of important indicators such as: petroleum production, total, $\mathrm{mln} t$; petroleum consumption, with export processing, total, mln t; petroleum imports, total, mln $\mathrm{t}$ - prediction models were built in the sphere of petroleum industry by using the group method of data handling for the above indicators and made the following conclusions and received such results:

- forecasted the growth of petroleum production from 5,4 mln t in 2006 to $9,14 \mathrm{mln} \mathrm{t}$ in 2020.

- forecasted the growth of petroleum consumption from $19.5 \mathrm{mln} \mathrm{t}$ in 2006 to $28,99 \mathrm{mln} \mathrm{t}$ in 2020 .

- forecasted the growth of oil imports from 15,5 mln t in 2006 to $28.23 \mathrm{mln} \mathrm{t}$ in 2020.

- forecasted the decreasing of gas imports from 54,1 in 2006 to 18.89 in 2020.

\section{References}

[1] A.G. Yvahnenko, and Y.P. Zaichenko, Adoption decisions based on selforganization. Moscow, USSR: "Soviet Radio", 1976, 280 p.

[2] I. Kravets, and G. Afanasyeva, "Research methods of statistical and predictive analysis for autoregressive models", Scientific Papers: Scientific-methodical journal, vol. 93, 2009.

[3] A. Tatarkyn and V. Yakovlev, The economic security of the region: the unity of theory, research methodology and practice. Ekaterinburg, Russia: Publisher Ural, 2007.

[4] J. Savenko, Energy balance: some questions of theory and practice. Moscow, Russia: Energy, 2011.

[5] A. Egorov, Method of analysis and energy balances of industrial enterprises. St. Petersburg, Russia, 2012.

Стаття надійшла до редакиії 23.03.2017 p. 